\title{
The Impact of Using Flipped Learning Strategy on Developing Listening Skills of 7th Grade Female Students in the United Arab Emirates
}

\author{
May A. Awad \\ Al Ain University, United Arab Emirates \\ Ibtehal M. Aburezeq \\ Al Ain University, United Arab Emirates
}

\begin{abstract}
This study aimed to examine the impact of Flipped Learning Strategy on developing listening skills of 7th grade female students in the United Arab Emirates. The study sample consisted of (44) female students selected by using the convenience sampling method from the Emirates Private School during the academic year of 2019 -2020. Those female students were distributed into two groups: An experimental group (22 students) and control group ( 22 students). The experimental group was taught the listening skills by using the Flipped Learning Strategy, and the control group was taught by the traditional method. To achieve the purpose of the study and answer its questions, a listening skills test was developed and its validity and reliability were also checked. At the end of the experiment which lasted for six weeks, the post-test of listening skills was carried out. The appropriate statistical methods were used to analyze the collected data. The results of the study showed that there were statistically significant differences between the two groups in the total score of the listening post-test and its three levels (audible discrimination, audible interpretation, audible criticism in favor of the experimental group. This indicates that the flipped learning strategy had a positive impact on developing the listening skills of sample students. Given such results, a number of recommendations were provided.
\end{abstract}

Index Terms — strategy, flipped learning, listening skills, seventh grade

\section{INTRODUCTION AND RELATED LITERATURE}

Language is a tool for thinking, contact and communication between individuals, by which heritage has been kept and circulated through generations, and through it, people of one society have been able to converge, understand and create a common basis through which their ideas and creativity crystallize and march together towards progress and evolution through time. Language with different skills is a means of transferring and exchanging feelings, sensations, experiences, ideas, and knowledge from one individual to another. Language consists of several skills: listening, speaking, reading, and writing, where language communication is carried out through those skills that represent the forms of language use, and each individual skill is highly important for them and for the rest of the skills, each skill depends during its use on the individual's mastery of other interrelated skills, in order that some of those skills influence and be influenced by the other, and Arabic language skills require the individual's awareness and attention to achieve language growth and proficiency (Al-Mashharawi and Hallas, 2018).

Al-Obaid and Al-Shayea (2015) stated that modern technology has added another dimension to the traditional Strategies of teaching and methodologies, and contributed to devoting the principle of uniqueness of education, which takes into account the individual differences of learners and increases the motivation for learning. Similarly, the existence of many strategies and methodologies based on the technology of education in the classroom which contributes to the effectiveness of the educational process, such as strategies based on PowerPoint presentations, interactive online education, virtual environments in education, the provision of learning resources, as well as evaluation and diagnosis. The concept of flipped learning has emerged in the 21 st century as a modern technologybased strategy for designing lessons according to the student's preparation, abilities and circumstances in order to achieve the target goals of learning and teaching where flipped learning uses many modern technologies and the web to help the teacher design lessons supported by videos, audio files, or PowerPoint presentations, so that the learner can view and review them at home before attending the lesson.

Flipped learning is based on the constructivist theory which views learners as interactive thinkers with the world around them in an active collaborative atmosphere that helps to make use of time in class, and helps guide learners to learning resources (Al-Ghamdi and Al-Ansari, 2018). In addition, the constructivist theory focuses on the activity of the learner, and his obtaining a meaningful learning by understanding what he learns, and seeking to build scientific concepts and knowledge (Al-Jallad and Al-Dulaimi, 2018). The constructivist theory is one of the most educational theories called for by educators to design diverse educational attitudes, such as Brunner (1990), Vygotsky (1978), and 
Dewey (1916). The pioneers of constructivist theory point to the importance of transitioning learning by linking educational tasks with life skills related to the subject of education (El-Tahan, 2014).

$\underline{\text { Related literature }}$

Teaching strategies have varied and diversified throughout the ages. There are many strategies that assist the teacher in the learning process; some are done individually and some are done collectively. However, there is no better educational strategy than another; rather, selection is made according to what is appropriate to the educational content and learners and in order to achieve educational goals in quality and effectiveness. This diversity is due to an inevitable result of the development of the philosophy of education, the multiplicity of educational goals, the development of learning and teaching theories, and the development of technological and technical means which added other dimensions to education. As a natural result of this diversity in education strategies, the classifications associated with them varied. Some of them focus on the teacher and are called teacher-dependent strategies, such as explanations, presentations, lectures, etc., and they are strategies that are subject to the authority of the teacher and his absolute control of the teaching-learning process. The other type is the strategies that depend on the learner and consider him as the center of the educational process, such as programmed education, small groups, e-learning problem solving, educational portfolios, and other strategies (Zayer, Sabri, and Hassan, 2014).

The origins of flipped learning are traced back to the scientist Baker who was the first to think about using this technology, with the aim of transferring the curriculum to learners outside the classroom. Despite all the difficulties encountered to find the optimal method of transferring content, he continued to try until the emergence of the Learning Management System (LMS) in 1995, which enabled him to transfer educational content and lectures to students with ease (Baker, 2000) referred to in (Al-Ghamdi and Al-Ansari, 2018). Mortensen and Nicholson cited in the Belmonte, Sánche, \& Espejo study (Belmonte, Sánche, \& Espejo, 2019) define flipped learning as an approach to learning and teaching in which the roles of teacher and learner are reflected in the educational process. The concept of flipped learning has emerged in many places such as EDUCAUSE Foundation, which is distinguished in the activation of technology and modern techniques in education, which the Foundation refers to flipped learning as a model that presents cognitive content as a model lecture that can be seen at home as a duty, and discussion of content takes place within the classroom.

The problem of this study is summarized in the weakness of students in listening skills, as the researcher noticed through her teaching for several years that the listening skill of her students were weak and needed more attention from those concerned to improve them and work on their development. Furthermore, there are also some studies that point out the weakness of students in listening skills, such as the study of Al-Mashharawi and Hallas (2018), and the study of Mansi (2018). This study attempted to tackle this problem by answering the following questions:

Key question:

Are there statistically significant differences at the confidence level $(\alpha \leq 0.05)$ between the average grades of seventh graders between the experimental and control groups in the combined post-test listening skills attributable to the teaching strategies of Flipped learning and the usual method?

Three sub-questions emerged from the main question:

Are there statistically Significant differences at a confidence level $(\alpha \leq 0.05)$ between the average grades of seventh graders in the experimental and control groups between the post-test of listening skills related to audible discrimination attributable to the teaching strategies of Flipped learning and the usual method?

Are there statistically Significant differences at a confidence level $(\alpha \leq 0.05)$ between the average grades of seventh graders in the experimental and control groups in the posttest of listening skills related to the audible interpretation attributable to the teaching strategies of Flipped learning and the usual method Flipped learning and the usual method?

Are there statistically Significant differences at a confidence level $(\alpha \leq 0.05)$ between the average grades of seventh graders between the experimental and control groups in the post test of listening skills related to audio criticism attributed to the teaching strategies of Flipped learning and the usual method flipped learning and the usual method?

This study aimed to find out the effectiveness of using the flipped learning strategy in developing the listening skills of seventh graders in the emirate of Abu Dhabi.

The importance of the current study emerges from the theoretical and practical perspectives in the following aspects:

Significance of the study from a theoretical point of view

The theoretical importance of conducting this study lies in providing a theoretical framework on the effectiveness of using the flipped learning strategy in developing listening skills, due to the scarcity of studies that dealt with the effectiveness of using the flipped learning strategy and its ability to improve and develop listening skills in the Arabic language in the Emirate of Abu Dhabi. In addition, this study is consistent with the recent policy of the United Arab Emirates in activating the role of the learner in building and acquiring knowledge.

Significance of the study from a practical point of view

The current study is a recent study that contributes to drawing the attention of those concerned in the Ministry of Education to the importance of the effectiveness of using the flipped learning strategy in developing listening skills in teaching Arabic, in addition to urging them to take advantage of educational technology and its applications available in the flipped learning strategy, and the techniques that work on consolidating the foundations of self-learning and mastering listening skills. The results of the study benefit curricula authors and developers in including modern teaching 
strategies, in addition to benefiting from the manner of applying this strategy in various educational situations that contribute to the development of listening skills as it is the basis for the rest of the language skills of speaking, reading and writing.

$\underline{\text { Study Scope and limitations }}$

The scope and limits of the study were as follows

Objective limits: This study was limited to teaching the following lessons (Optimism and Hope, Burj Khalifa, writing a narrative text) from the Arabic language book for the seventh grade, Part Two.

Human limits: seventh graders in the United Arab Emirates.

Time limits: the study was applied during the second semester of the 2019-2020 academic year and the application lasted for six weeks.

Place limits: Emirates private school in Al Ain City affiliated to Department of Education and Knowledge in the Emirate of Abu Dhabi in the United Arab Emirates.

Procedural definitions:

Flipped learning strategy: is the art of class management in a direction opposite to the traditional trend, whereby the learner reviews and studies educational content at home based on learning technology, and the teacher plays the role of designer, mentor, and facilitator of in-class learning, so that the class time is exploited for enrichment, reinforcement and processing.

Listening skill: It is the skill through which sounds are received, understood and analyzed up to the ability to criticize and judge the listening, in order to achieve the growth of listening skill and mastery of it at its three levels their indicators (audio discrimination, audio interpretation, and audio criticism). In addition, this strategy involves effective communication between the sender and receiver, measured by a tool prepared by the researcher for this purpose.

Seventh grade: It is one of the grades of the second cycle, extending from grade 5-8, and the ages of students range between (12-13) years.

In the context of the search for the topic in theoretical literature and previous studies, the relevant studies were divided into two types: the first types surveys Arabic studies related to flipped learning and then foreign studies, while the second type included Arabic and then foreign studies related to listening.

First Type: Arabic studies related to flipped learning and then foreign studies

In a study by Mansi (2018) aiming at identifying the effectiveness of the use of flipped learning strategy in the development of listening skills and trends towards it, the researcher followed the semi-experimental approach to achieve the objectives of the study, whereby the researcher designed two tools for the study, namely: An achievement test of critical listening skills, and a scale of attitudes towards a flipped learning strategy. The study sample consisted of (85) tenth grade students. They were chosen intentionally and divided into two groups: experimental and control groups. Using the appropriate statistical treatments, it was found that there were statistically significant differences at the confidence level $(\alpha \leq 0.05)$ between the two groups in favor of the experimental group due to the use of the flipped learning strategy.

The second study was conducted by Al-Zubaidi (2018). The study aimed to identify the use of the flipped learning strategy in academic achievement in the Arabic language in terms of developing self-learning skills. The researcher followed the quasi-experimental approach to achieve the objectives of the study, and an achievement test and a questionnaire were used to measure self-learning skills as tools for the study. The sample consisted of (70) female students from the tenth grade. The results of the study showed the performance of the experimental group which used the flipped learning strategy was significantly better than the performance of the control group, and concluded that the flipped strategy raised the level of self-learning among female students in the Arabic language.

Both researchers, Al-Ghamdi and Al-Ansari (2018) investigated the effectiveness of the use of flipped learning in developing self-learning skills and cognitive achievement. To achieve this goal, both researchers followed the semiexperimental approach and used the self-learning skills scale and the cognitive achievement test for a sample of 68 firstgraders in the social and national school subjects using the flipped strategy. After the study was applied, the results showed significant differences in favor of the experimental group in both the self-learning skills scale and the cognitive achievement test. The results also showed a statistically significant correlation between performance in both scales among the experimental group students studied using flipped learning.

A study titled Integrating Flipped Learning in Traditional Classrooms to Enhance Learning English Listening and Speaking Skills for Non-Native Speakers and Enhance Participation by Amir Yousefi (2019) investigated the effectiveness of the flipped strategy. The researcher designed his experiment according to the experimental method. The sample consisted of (67) university students from Iran. The sample was divided into three groups; the set of Flipped Structured Learning, Flipped Semi-Structured Learning, and Traditional Learning. The researcher used the instant messaging application (Telegram) as an online platform to implement the study, and its tools were a listening test, a speaking test, and a questionnaire. The results of the study, after applying the strategy on the experimental group, showed that there were statistically significant differences in favor of the experimental group in the listening and speaking test, and the results showed that flipped learning can help learners improve listening and speaking skills in second language learning, and lead to an increase in motivation to participate in materials and activities that take place 
outside classroom, and that flipped learning can contribute to increasing the quality of learning a second language and facilitate its teaching by teachers, compared to traditional learning.

As for the study of Kırmızı \& Kömeç, (2019), it aimed to know the effect of flipped learning on receptive vocabulary and productivity in learning. The quasi-experimental approach was followed to achieve the objectives of the study. The number of sample members was (58) students in the secondary stage. The researchers used a test to measure vocabulary, and an open questionnaire as a study tool. The results indicated that there were statistically significant differences in favor of the experimental group due to the use of flipped learning. The results of the questionnaire also showed that the learners demonstrated positive attitudes towards practical activities that take place in the classroom. They found that flipped learning is dynamic, collaborative, and effective.

Khadragy (2016) also conducted a study aimed at exploring the effect of using the teaching inversion method (flipped learning) on reading performance in the English language, whereby the researcher used the quasi-experimental approach to achieve the objectives of the study, and the researcher worked on designing an educational program that was implemented in a period of 8 weeks. The program included a set of tools, namely: educational films and a social media channel with CDs, with the application of three exams, the first is diagnostic, a pre-test and a post-test. The number of sample members was (55) female students, who were divided into two groups: experimental and control. The results showed a positive impact on the level of performance on the reading skills in the experimental group.

The Second Type: listening-related-studies

Al-Suwairki (2019) conducted a study aimed at investigating the necessary listening skills to achieve academic excellence among students at King Abdul-Aziz University. To achieve the objectives of the study, the researcher followed the descriptive analytical approach. The study sample consisted of (243) students, and the researcher prepared a questionnaire to determine the necessary listening skills for university students and designed a listening skills test. The study found that a list of the listening skills necessary to achieve excellence in the study amounted to (5) main skills associated with (25) sub-skills in the skills of comprehension and audible discrimination. The study also showed the extent to which students need listening skills and their necessity in their scientific and practical life inside and outside the university.

Al-Kadam (2019) conducted a study on the impact of YouTube in raising the level of both listening and speaking skills among female students. The researcher followed the descriptive and analytical approach to achieve the objectives of the study, and prepared a questionnaire that was distributed to the sample members of (42) female students of the Institute of Arabic Language Teaching for Non-speakers at Princess Nourah Bint Abdulrahman University. The results of the study showed that the level of use of YouTube by female students was mostly average, and that the level of female students in listening and speaking skills was also average, and the study showed a statistically significant impact on the use of YouTube in raising the level of both listening and speaking skills among female students.

Mansi (2019) conducted a study that aimed to find out the effect of employing digital stories in developing the listening skills of ninth grade students in Jordan. To achieve the objectives of the study, the researcher followed the experimental approach. The sample consisted of (64) ninth grade students who were divided into two experimental and control groups. The researcher used the listening skills test as a tool for the study, and the results showed that there were statistically significant differences at the confidence level $(\alpha \leq 0.05)$ in favor of the experimental group students who studied using digital stories in the listening skills test.

Al-Mashhrawi and Hallas (2018) conducted a study to reveal the effectiveness of a multimedia program in developing listening skills in Gaza. The two researchers followed the experimental approach to achieve the objectives of the study, and a multimedia-based program, written test and an observation card were used for the sixth grade students. The study indicated that there were statistically significant differences in favor of the experimental group in the post test of listening skills, as well as the presence of statistically significant differences in favor of the experimental group in the post-test of the note card compared to the control group.

As for the foreign studies related to listening, the first study was conducted by Erkek and Batur (2019). It aimed to build actual suggestions for developing critical listening skills. The researchers used the descriptive analytical approach to achieve the objectives of the study by analyzing the curriculum at the fifth and sixth levels of the preparatory stage in Turkey on activities related to the development of critical listening skills after preparing a list of critical listening skills. The results of the study indicated neglect of listening skill in the curriculum and in theoretical literature, with a dearth of studies centered on activities that develop critical listening skill.

Kök (2018) conducted a study on the relationship between the listening comprehension strategy and the mastery of listening comprehension for university students. To achieve the objectives of the study, the researcher followed the quasi-experimental approach to a sample of (44) students in the Department of English Language Teaching. The researcher used three listening tests with time intervals in order to measure listening comprehension. Through the experimental treatment that was applied for a period of (6) weeks, it was found that there is a positive relationship between the level of using the listening comprehension strategy and the mastery of listening comprehension among university students in favor of the experimental group.

On the other hand, Kirbas (2017) conducted a study aimed at knowing the effect of the cooperative learning method in developing listening and comprehension skills for eighth grade students in several schools in the Turkish province of Erzurum, where the experimental method was followed to achieve the objectives of the study, and the number of 
sample members was 75 students. The researcher used the listening test as a tool for the study. The results of the study showed that there were statistically significant differences in favor of the experimental group that studied listening using the cooperative learning method.

Caruso, Colombi, \& Tebbit (2017) conducted a study on the effectiveness of listening teaching according to blended learning for developing and evaluating listening skills in a second language. To achieve the objectives of the study, the researchers used the quasi-experimental approach. A set of listening tests and a questionnaire were prepared and applied to a sample of students of the University of Western Australia and the number of the sample was (81). The results of the study showed that there were statistically significant differences in favor of the experimental group that studied listening according to mixed learning, in addition to the students' preference for learning using blended learning by building positive perceptions by students for assessment through World Wide Web

\section{METHODOLOGY}

The study adopted the quasi-experimental approach to achieve the objectives of the study, as it is the most appropriate approach for the purposes of the study. The purpose of the study is to find out the effectiveness of using the flipped learning strategy in developing the listening skills of seventh grade female students in the Emirate of Abu Dhabi.

Study Sample:

The study consisted of (44) female students, who were chosen intentionally.

Study tool:

To implement the study, the researcher designed the tool represented in the listening skills test to know the effectiveness of the flipped learning strategy in developing the listening skills of seventh grade female students in the Emirate of Abu Dhabi. To verify the validity of the tool, it was presented to a group of arbitrators with experience and expertise from specialists in the field of curricula and teaching methods, and supervisors. and teachers of the Arabic language numbering (12) arbitrators.

TABLE No. (1):

The VAlues Of THE CONSISTENCY COEFFICIENTS For THE Listening SKILls Test

\begin{tabular}{|l|l|l|}
\hline Level & No. of Questions & Stability coefficient value \\
\hline Audible Discrimination Skill & 5 & 0.659 \\
\hline Audible Interpretation Skill & 5 & 0.739 \\
\hline Audible Criticism Skill & 5 & 0.725 \\
\hline Combined listening Skills & 15 & 0.857 \\
\hline
\end{tabular}

Table 1 shows the stability coefficient value for the combined listening skills test (0.857), the value of the stability coefficient for the listening skills test related to audible discrimination (0.659), the stability coefficient value for the listening skills test related to the audible interpretation (0.739) and the listening skills test related to the audible criticism (0.725); since all the values of the constancy coefficients mentioned in Table 1 range from 0.00-1.00), they are considered acceptable and suitable for study purposes (Carmines \& Zeller, 1979).

Table 1 shows the consistency coefficient value for the combined listening skills test was (0.857), and the value of the consistency coefficient for the listening skills test related to audible discrimination was (0.659), while the consistency coefficient value for the listening skills test related to the audible interpretation was (0.739) and the listening skills test related to the audible criticism was (0.725). Since all the values of the consistency coefficients mentioned in Table 1 range from (0.00-1.00), they are considered acceptable and suitable for study purposes (Carmines \& Zeller, 1979)

Study Plans:

To prepare the study plans, the theoretical literature and previous studies associated with the study, such as the Zubaidi Study (2018), the Bergmann \& Sams study (2014), as well as the teacher's guide and the benefit from the experience of the teacher responsible for the implementation of the study and her observations on the preparation of the study plans were reviewed. The validity of the lesson plans was verified and presented in its initial form to a group of arbitrators specialized in the curricula and methods of teaching Arabic, in addition to a number of (12) Arabic language supervisors and teachers.

The Equivalence of the Two Study Groups

To verify the equivalence of the two groups of the study, the test was applied to the two groups before applying the study, and then the average and standard deviations of the scores of the students of the two groups were calculated. To find out the statistical significance of these differences, the Paired Sample T-Test was used, which shows the tabular (T) value and the value of $(\mathrm{C})$ calculated, and Table No. (2) shows this. 
TABLE NO. (2):

Arithmetic Averages, Standard Deviations, VAlue Of (T) And LeVel OF SignificAnCE For EXPERIMENTAL And Control Groups In The PRE-TEST OF THE LISTENING SKILLS.

\begin{tabular}{|l|l|l|l|l|l|l|}
\hline Group & NO. & Arithmetic average & Standard deviation & $\begin{array}{l}\text { Calculated value of } \\
(\mathrm{T})\end{array}$ & $\begin{array}{l}\text { Tabular value of } \\
(\mathrm{T})\end{array}$ & $\begin{array}{l}\text { Level of semantic } \\
\text { Experimental }\end{array}$ \\
\hline Control & 22 & 8.3 & 1.28 & 1.62 & 2.02 & Not \\
semantic
\end{tabular}

Table No. (2) shows that there are no statistically Significant differences in the Arithmetic averages and standard deviations between the scores of the experimental and control groups in the pre-test, as the calculated (T) value (1.62) was less than its tabular value, which amounted to (2.02). This indicates that there are no statistically significant differences at the confidence level $(\alpha \leq 0.05)$ due to the effect of the group, which indicates the equality of the two study groups before the study was implemented (Rowntree, 2000).

Test time:

To determine the appropriate time for the test, the arithmetic average of the time period for the test applied to the pilot sample was calculated for the first student to finish the test and the last student to finish the test in the exploratory sample, where the arithmetic average was found through the following equation:

Arithmetic average $=($ the last student took the time + the first student took the time $) / 2$

After calculating the result of the equation, it was found that the appropriate test time is (40) minutes.

Procedures of the Study:

The following procedures were followed in the study:

1. Reviewing educational theoretical literature and previous studies related to the subject of the study.

2. Determining the time plan for the implementation of the study, which started from 01/26/2020 to 05/03/2020. (11) lessons covering three lessons: optimism and hope, Burj Khalifa, and writing a narrative text.

3. Preparing a list of listening skills, selecting the listening text, preparing a listening skills test, and lesson plans for the targeted lessons.

4. Checking the apparent validity of the tool. Obtaining a task facilitation letter directed from the Ministry of Education for private schools in the Emirate of Abu Dhabi to facilitate the researcher's task, annex (7).

5. Applying the test to the exploratory sample to verify the consistency of the test and to determine the time of the test.

6. Conducting a pre-test for listening skills on the experimental and control groups on 26/01/2020 to verify the equivalence of the two groups and implementing the study according to the flipped learning strategy for the experimental group, and based on the usual method for the control group, and conducting the post-test of listening skills on the two study groups after the end of the study's implementation, on 05/03/2020. The test was corrected within the model answer table.

7. Collecting Data and processing them statistically to present, interpret and discuss the results, and then formulate recommendations based on the results of the study.

\section{$\underline{\text { Variables }}$}

The current study included the following variables:

The independent variable is the teaching method and has two levels: the flipped learning strategy and the regular method.

Dependent variable: listening skills.

Statistical Analysis

The researcher answered the study questions to achieve its objectives by using the following statistical methods:

Cronbach's alpha coefficient to calculate the consistency coefficient of the test.

Arithmetic averages and standard deviations to verify the equivalence of the two study groups.

Calculating the value of $(\mathrm{T})$ using the (Paired Sample T-Test) to detect the significance of the statistical differences between the scores of the experimental and control groups in the listening skills test.

\section{RESUlTS AND ANALYSIS}

This chapter presents the Results of the current study, where they were presented starting with the main question and then the sub-questions and came as follows:

Results related to the main question, which states: are there statistically significant differences at the confidence level $(\alpha \leq 0.05)$ between the average grades of seventh graders in the experimental and control groups on the combined aftertest listening skills attributable to the teaching strategy according to Flipped learning and the usual method?

To answer the question, the Arithmetic averages and standard deviations of the scores of both the experimental and control groups in the telemetry test of listening skills were calculated together, as shown in Table 3. 
TABLE NO. 3:

Arithmetic Averages, Standard Deviations, Value (V) And Confidence LeVel Of The Scores Of The Experimental And Control GROUPS IN THE POST-TEST OF COMBINED LISTENING SKILLS.

\begin{tabular}{|l|l|l|l|l|l|l|}
\hline Group & NO. & Arithmetic average & Standard deviation & $\begin{array}{l}\text { Calculated value of } \\
(\mathrm{T})\end{array}$ & $\begin{array}{l}\text { Tabular value of } \\
(\mathrm{T})\end{array}$ & Level of semantic \\
\hline Experimental & 22 & 14.09 & 0.75018 & 1.92 & 1.72 & Statistically \\
\hline Control & 22 & 7.97 & 1.65994 & & \\
\hline
\end{tabular}

Table (3) shows that there are differences in the arithmetic averages between the scores of the experimental and control groups in the post-test of listening skills combined. The arithmetic average of the scores of the experimental group students was (14.09), which is greater than the arithmetic average of the scores of the students of the control group (7.97), and it appears that the calculated value of $(\mathrm{T})$ is greater than its tabular value at the confidence level $(\alpha \leq 0.05)$, as for the value of (T) ), the calculated value is (1.92) and the tabular (T) value is (1.72), and therefore there are statistically significant differences between the arithmetic averages of the scores of the experimental and control groups in the post-test of the combined listening skills.

Results related to the first sub-question :

The main question: Are there statistically Significant differences at the confidence level $(\alpha \leq 0.05)$ between the mean scores of seventh grade students in the experimental and control groups in the post- test of listening skills related to audible discrimination due to the teaching strategy according to the flipped learning and the usual method?

In order to answer the question, the arithmetic averages and standard deviations of the scores of each of the experimental and control groups were calculated in the post-test of listening skills related to audible discrimination, and Table No. (4) shows this.

TABLE No. (4):

Arithmetic Averages, Standard Deviations, T-Value And SignificAnce LeVel For The SCOREs Of The ExPERIMENTAL And Control Groups In The Post Test Of Listening SKILls RElATEd To Audible DiscriminAtion.

\begin{tabular}{|l|l|l|l|l|l|l|}
\hline Group & NO. & Arithmetic average & Standard deviation & Calculated value of (T) & Tabular value of (T) & Level of semantic \\
\hline Experimental & 22 & 4.68 & 0.47673 & 9.21 & 1.72 & Statistically semantic \\
\hline Control & 22 & 2.77 & 0.75162 & & \\
\end{tabular}

It is noted from Table No. (4) that there are differences in the arithmetic averages between the scores of the experimental and control groups in the post-test of listening skills related to audible discrimination. The arithmetic average of the scores of the students in the experimental group was (4.68), while the arithmetic average of the scores of the students in the control group was $(2.77$.(

It also turned out that the calculated $(\mathrm{T})$ value is greater than its tabular value at the confidence level $(\alpha \leq 0.05)$, as the calculated (T) value is (9.21) and the tabulated (T) value is (1.72). Thus, there are statistically Significant differences between the arithmetic averages of the scores of the students of the experimental and control groups in the post- test of listening skills related to audible discrimination.

Results related to the second sub-question: Are there statistically significant differences at the confidence level of $(\alpha \leq 0.05)$ between the mean scores of seventh grade students in the experimental and control groups in the post-test of listening skills related to the audible interpretation due to the teaching strategy based on flipped learning and the usual method?

In order to answer the question, the arithmetic averages and standard deviations of the scores of each of the experimental and control groups were calculated in the post-test of listening skills related to audible discrimination, as shown in Table (5.)(

TABLE NO. (5):

Arithmetic Averages, Standard Deviations, T-VAlue And CONFIDENCE LEVEl For THE SCOREs Of THE EXPERIMENTAL AND CONTROL GROUPS IN THE POST-TEST OF LISTENING SKILLS RELATED TO AUDIO INTERPRETATION

\begin{tabular}{|l|l|l|l|l|l|l|}
\hline Group & NO. & Arithmetic average & Standard deviation & Calculated value of (T) & Tabular value of (T) & Level of semantic \\
\hline Experimental & 22 & 4.81 & 0.39477 & 12.02 & 1.72 & Statistically semantic \\
\hline Control & 22 & 2.59 & 0.66613 & & \\
\hline
\end{tabular}

It is noted from Table No. (5) that there are differences in the arithmetic averages between the scores of the experimental and control groups in the post-test of listening skills related to the audible interpretation; The arithmetic average of the scores of the students in the experimental group was (4.81), which is greater than the arithmetic average of the scores of the students of the control group, which amounted to (2.59), and it turned out that the calculated (T) value is greater than its tabular value at the confidence level of $(\alpha \leq 0.05)$, as the calculated (T) value is (12.02) and the tabular (T) value is (1.72), and therefore there are statistically significant differences between the arithmetic averages of the scores of the students of the experimental and control groups in the post-test of listening skills related to the audible interpretation.

Results related to the third sub-question: Are there statistically significant differences at the confidence level of $(\alpha \leq 0.05)$ between the mean scores of seventh grade students in the experimental and control groups in the post-test of listening skills related to audio criticism due to the teaching strategy based on flipped learning and the usual method? 
In order to answer the question, the arithmetic averages and standard deviations of the scores of each of the experimental and control groups were calculated in the post-test of listening skills related to audible discrimination, as shown in Table (6)

TABLE NO. (6):

Arithmetic Averages, Standard Deviations, T-VAlue And Confidence LeVel For The Scores Of THE EXPERIMENTAL AND Control Groups In THE POST-TEST OF LISTENING SKILls RELATED TO AUDIO CRITICISM

\begin{tabular}{|l|l|l|l|l|l|l|}
\hline Group & NO. & Arithmetic average & Standard deviation & Calculated value of (T) & Tabular value of (T) & Level of semantic \\
\hline Experimental & 22 & 4.59 & 0.59033 & 7.12 & 1.72 & Statistically semantic \\
\hline Control & 22 & 2.40 & 1.00755 & & \\
\hline
\end{tabular}

It is noted from Table No. (6) that there are differences in the arithmetic averages between the scores of the experimental and control groups in the post-test of listening skills related to audible discrimination. The arithmetic average of the scores of the students in the experimental group was (4.59), which is greater than the arithmetic average of the scores of the students of the control group, which reached (2.40). Also, it turned out that the calculated (T) value is greater than its tabular value at the confidence level of $(\alpha \leq 0.05)$, where the calculated (T) value is (7.12) and the tabular ( $\mathrm{T}$ ) value is (1.72), and therefore there are statistically Significant differences between the arithmetic averages of the scores of the students of the experimental and control groups in the post-test of listening skills related to audio criticism.

\section{DISCUSSION}

This chapter deals with a discussion of the results obtained from the current study and their interpretation, with a presentation of a set of recommendations that were drawn in the light of the results of the current study, and they came as follows:

Discussing the results related to the main question:

The results of the study showed that there were statistically significant differences at the confidence level of $(\alpha \leq 0.05)$ between the arithmetic averages of the scores of the female students in the experimental and control groups in the posttest of listening skills combined. This difference was in favor of the experimental group that was taught using the flipped learning strategy. The previous result can be explained by the use of the flipped learning strategy on the study sample, where the use of flipped learning in teaching the experimental group had a significant impact on the development of listening skills. The flipped learning strategy stimulates the motivation for self-learning among the students and gives them the opportunity to review the submitted materials more than once in proportion to the abilities of each student. Thus, it contributes to taking into account individual differences and providing flexibility for the student to review and repeat the educational content as needed and at the appropriate time for her.

Discussing the results related to the first sub-question:

The results of the study indicated that there were statistically significant differences at confidence level of $(\alpha \leq 0.05)$ between the arithmetic averages of the scores of the students in the experimental and control groups in the post-test of listening skills related to audible discrimination. This difference was in favor of the experimental group that was taught using the flipped learning strategy. The researcher explains this result that the experimental group was positively affected by the flipped learning strategy, and this was reflected in the development and improvement of the audible discrimination skills of the students. The flipped learning strategy has contributed to increasing the motivation for learning and self-learning, which contributed to raising the efficiency and comprehension capacity of students, in addition to the flexibility and taking into account the individual differences offered by the flipped learning strategy to students in dealing with clips and recordings sent by the teacher, so that each student, according to her abilities, was able to review the submitted material several times, in addition to the activities applied in the classroom, which were complementary to the submitted sections. Likewise, the strategy contributed to increasing the interaction of students and increasing their interest and development and improvement of audible discrimination skills.

Discussing the results related to the second sub-question:

The results of the study showed that there were statistically significant differences at the confidence level of $(\alpha \leq 0.05)$ between the arithmetic averages of the scores of the students in the experimental and control groups in the post-test of listening skills related to audio interpretation in favor of the experimental group that was taught using the flipped learning strategy. It is possible to trace this result that was found out in the study to the fact that the experimental group was subjected to the flipped learning strategy in learning the Arabic language, which led to the ease of reviewing and understanding the material in a timely manner for the students and according to their abilities and needs through the availability of educational content for the students and the possibility to refer to it smoothly and easily. This was reflected in improving the students' skills in interpreting and understanding audio content, as the strategy allows flexibility in following up the audio material by the students at the appropriate pace for them, and this result is confirmed by the study of Al Kadam (2019), the study of Mansi (2019), and the study of Al-Suwerki (2016). ), and Khadragy's study (Khadragy, 2016). These studies confirmed that integrating flipped learning into traditional classrooms would enhance learning language skills in general and listening skills in particular, and enhance active 
participation and motivate learners to learn listening skills, with better results in listening skills tests, in addition to having a tendency and preference for flipped learning on the part of the learners.

The results of the study indicated that there were statistically Significant differences at the confidence level of $(\alpha \leq 0.05)$ between the arithmetic averages of the scores of the students in the experimental and control groups in the post-test of listening skills related to audio criticism in favor of the experimental group that was taught using the flipped learning strategy. This result may be due to the procedures followed in the flipped learning strategy and to the time it gives to students in reviewing ideas and educational content sent through the media in a way that provokes critical thinking and contributes to its development according to the student's abilities and preparations. This illustrates the importance of using the flipped learning strategy in developing the individual listening skills. This finding is consistent with the Results of the study of Al-Fawzan (2019), and the study of Al-Mashhrawi and Hallas (2018), which showed the effectiveness of using the flipped learning strategy in developing listening skills through tests and applied programs Similarly, this finding is consistent with the results of the studies by Kök (Kök, 2018), and the Kirbas (2017), and Eric and Batur (Erkek \& Batur, 2019), which showed that the use of modern educational strategies such as the flipped learning strategy contributes to the development of listening skills related to audio criticism and stimulates the motivation to listen among learners.

$\underline{\text { Recommendations }}$

Based on the results of the study, the researcher recommends the following:

1. Inclusion of the flipped learning strategy within the modern strategies in teaching Arabic and the various curricula that the Ministry of Education is working to develop and modify on a regular basis.

2. Training educational cadres to utilize the flipped learning strategy to motivate learners, raise their level, and develop listening and Arabic language skills.

3. Providing training opportunities for students on how to benefit from the flipped learning strategy in order to develop listening skills in the Arabic language, which is reflected on the rest of the skills in the Arabic language.

4. Overcoming the obstacles that stand in the way of implementing the flipped learning strategy to provide fun and suspense in developing listening skills in the Arabic language at all levels of study.

5. Conducting more studies on the flipped learning strategy on different grades, a larger sample, and different variables such as speaking skill, reading skill, or writing skill.

\section{CONCLUSION}

Perhaps the flipped learning strategy as a relatively recent educational strategy on the one hand and based on educational technology on the other hand is one of the strategies that mainly support the formation of the learners' listening skills as listening skills require accuracy, focus and attention to listening to speech, with continuous training and rehearsal until the learner reaches the degree of mastery of listening skills, starting from distinguishing the audible through the interpretation of the audible and ending with the criticism of the audible. This is exactly what the flipped learning strategy offers through its various techniques that include videos and recordings. Audio and presentations which allow the learner to listen to the text with concentration, with frequent repetition whenever necessary.

In addition, the flipped learning strategy provides the educational content to be reviewed and verified individually in a way that supports the uniqueness of education by consideration of individual differences and needs. This contributes greatly to the formation and building of the learner's listening skills and develops them, in addition to stimulating the learner to ask questions and take notes while listening, which contributes to the development of the skills of criticism and judgment. This clear relationship of the flipped learning strategy and its impact on developing listening skills is what prompted the researcher to link them in this study.

\section{REFERENCES}

[1] Al Fawzan, Muhammad bin Ibrahim. (2019). The effect of a proposed program on developing some listening skills among students of the Arabic Linguistics Institute. Journal of Educational Sciences, 31(1), 71-49.

[2] Al Ghamdi, Maha and Al-Ansari, and Dad. (2018). The effectiveness of employing the flipped learning strategy in developing self-learning skills and cognitive achievement in the social and national studies course for first-level secondary female students in the city of Taif. International Journal of Educational Research, 42(3), 196-236.

[3] Al Jallad, Maged Zaki; Al-Dulaimi, Montaser (2018). The effect of using the seven-cycle learning strategy on the achievement of the eighth-grade students in the unit of jurisprudence and the development of their deductive thinking skills. International Journal of Educational Research. Emirates University. 42(1) Jan, 64-97.

[4] Al Kadam, Mashael Bint Nasser. (2019). The impact of YouTube in raising the listening and speaking skills of female students of the Institute for Teaching Arabic to Speakers of Other Languages at Princess Nourah bint Abdulrahman University in the Kingdom of Saudi Arabia. Journal of the College of Basic Education for Educational and Human Sciences (42), 40-412.

[5] Al-Mashharawi, Hassan Salman and Hallas, Daoud Darwish. (2018). The effectiveness of a multimedia-based program in developing the listening skills of sixth graders. Specialized International Journal, 7(7), 101-114.

[6] Al Obaid, Afnan Abdel-Rahman and Al-Shaya, Hessa Mohammed. (2015). Educational technology foundations and applications. Riyadh: Al-Rushd Library Publishers. 
[7] Al Suwerki, Muhammad Ali. (2019). The necessary listening skills for academic excellence among students of King Abdulaziz University, "An Analytical Study". The Arab Journal of Educational and Psychological Sciences. (6), 262-241.

[8] Al Tahhan, Jassim Muhammad Ali. (2014). E-learning: modern prospects for developing economic performance. Al-Ain: University Book House.

[9] Al Zubaidi, the statement of Muhammad Ahmed. (2018). The effect of using the flipped learning strategy on academic achievement in Arabic language and the development of self-learning skills for tenth grade students. Jordan: The University of Jordan, 1-18.

[10] Amiryousefi, M. (2019). The Incorporation of Flipped Learning into Conventional Classes to Enhance EFL Learners' L2 Speaking, L2 Listening, and Engagement. Innovation in Language Learning and Teaching, 13(2), 147-161.

[11] Belmonte, J., Sánche, P., \& Espejo, d. (2019). Projection of the Flipped Learning Methodology in the. Journal of New Approaches in Educational Research, 8(2), 184-200.

[12] Bergmann, J., \& Sams, A. (2014). Flipped Learning: Gateway To Student Engagement. United States of America: International Society for Technology in Education World rights reserved.

[13] Carmines, E. G., \& Zeller, R. A. (1979). Reliability and validity assessment. Thousand Oaks, CA: Sag

[14] Caruso, M., Colombi, A., \& Tebbit, S. (2017). Teaching how to Listen. Blended Learning for the Development and Assessment of Listening Skills in a Second Language. Journal of University Teaching \& Learning Practice, 14(1), 1-19.

[15] Erkek, G., \& Batur, Z. (2019). Actıvity suggestions for 1mproving critical listenıng skılls. Educational Research and Reviews, 14(17), 639-646.

[16] Hallas, Daoud Darwish and Al-Shobaki, Maha Mohamed Ahmed. (2017). The effectiveness of a program based on listening skills in developing the reading skills of the fourth-grade girls in Gaza. International Journal of Educational and Psychological Studies, 2(2), 218-240.

[17] Khadragy, S. (2016, September). The Impact of the Flipped Classroom Model of Instruction on the Reading Achievement of Ninth Grade Female Emirati students in the Qurtoba Public School in Dubai. The British University in Dubai. Faculty of Education.

[18] Kirbas, A. (2017). Effects of Cooperative Learning Method on the Development of Listening Comprehension and Listening Skills. International Journal of Languages' Education and Teaching, 1(5), 1-17.

[19] Kırmızıa, Ö., \& Kömeç, F. (2019). The impact of the flipped classroom on receptive and productive vocabulary Learning. Journal of Language and Linguistic Studies, 15(2), 437-449.

[20] Kök, I. (2018). Relationship between Listening Comprehension Strategy Use and Listening Comprehension Proficiency. International Journal of Listening, 3(23), 163-179.

[21] Mansi, Ghada. (2018). The effectiveness of using the flipped learning strategy in developing critical listening skills for tenth grade female students in Jordan and their attitudes towards it. International Journal of Excellence Development, 16(9), 77-95.

[22] Mansi, Ghada Khalil. (2019). The effect of employing the digital story on developing the listening skills of the ninth-grade students in Jordan. International Journal of Excellence Development, 10(18), 3-17.

[23] Rowntree, D. (2000). Statistics without Tears: An introduction for nonmathematicians, new ed, London: Penguin.

[24] Zayer, Saad Ali and Sabri, Daoud Abdel Salam and Hassan, Muhammad Hadi. (2014). General teaching methods. Amman: Dar Safaa for Publishing and Distribution.

May Awad holds B. A. in Education/ Class Teacher from Damascus University and an M. A. of Education Arabic Language Curricula \& Instruction from Al Ain University. She worked as class teacher (in the field of Arabic, Science and Math Education for Elementary school) in United Arab Emirates for six years.

Ibtehal Mahmoud Aburezeq is the Vice President of Development and Follow up and Dean of Student Affairs at Al Ain University in the United Arab Emirates. She holds a B. A. in Arabic Language Literature, M.A. in Curriculum \& Instruction from University of Jordan, and a Ph. D. in Curriculum \& Instruction from University of Washington, USA.

Prior to joining Al Ain University, Prof. Aburezeq worked at University of Washington in Seattle and at Hashemite University in Jordan. Her research interests concentrate on teaching methods and techniques and engaging instructional technology in teaching. Her work has appeared in different national and international refereed educational journals and conferences. In 2014, she received the Distinguished Researcher Award among faculty members at Al Ain University. In addition, she is a reviewer of research projects and papers in several Journals.

Prof. Aburezeq held several administrative positions such as the Dean of Scientific Research and Graduate Studies and the Dean of College of Education, Humanities, and Social Sciences. 